\title{
The Relationship between Knowledge Management and Innovation Level in Mexican SMEs: empirical evidence
}

\author{
Gonzalo Maldonado Guzmán ${ }^{1}$ \\ PhD in Marketing \\ María del Carmen Martínez Serna ${ }^{2}$ \\ PhD in Administration \\ Domingo García Pérez de Lema $^{3}$ \\ PhD in Economics and Business
}

\begin{abstract}
The transformation of the current society from an industry-based economy to a knowledge management and innovation-based economy is changing the design and implementation of business strategies and the nature of the competition among the organizations which are mainly small and medium-size enterprises (SMEs). They struggle to survive in a market which is more demanding and competitive, so they see knowledge management as one of the most effective strategies that may help to enable the innovation activities into the businesses. For these reasons, this research paper has as a main goal to analyze the relationship between knowledge management and innovation in Mexican SMEs. The empirical analysis used 125 manufacturing SMEs (each SME having from 20 to 250 employees) as a sample to be carried out. The obtained results indicate that knowledge management has a positive impact in products, process, and management systems innovation.
\end{abstract}

Keywords: Knowledge Management, Innovation, SMEs.

\section{TOPIC: Small Business and Crisis}

\footnotetext{
1 Universidad Autónoma de Aguascalientes (México), Centro de Ciencias Económicas y Administrativas, Departamento de Mercadotecnia, E-mail: gmaldona@correo.uaa.mx.

2 Universidad Autónoma de Aguascalientes (México), Centro de Ciencias Económicas y Administrativas, Departamento de Mercadotecnia, E-mail: mcmartin@correo.uaa.mx.

${ }^{3}$ Universidad Politécnica de Cartagena (España), Facultad de Ciencias Empresariales, Departamento de Economía Financiera y Contabilidad, E-mail: domingo.garcia@upct.es.
} 


\section{INTRODUCTION}

The globalization of economy and a more demanding market with a high level of market demand are pushing the firms, mainly the small and medium-sized enterprises (SMEs), to re-structure their business strategies in order to update them to the current market demand. Similarly, different firms are considering knowledge management as a strategy that allows them to improve their level of competition (Audretsch \& Thurik, $2000 ; 2001 ; 2004)$ because knowledge is considered as an essential element to obtain a higher level of competitiveness and innovation in organizations (Corso et al., 2003; Chirico, 2008). For this reason, SMEs have to improve their business skills in order to manage more efficiently the knowledge generated by their employees so they can adapt faster to the external and internal changes that will allow them to apply innovation activities and, as a consequence, improve their economic fringes (Teece et al., 1997; Eisenhardt \& Martin, 2000).

In this sense, the current environment of business is changing rapidly from an industrialbased to a knowledge-based (Drucker, 1994; Van de Ven, 2004; Lu et al., 2008) by means of two essential elements. On one hand, we have the globalization of economy (Lu et al., 2008) while on the other hand we have fast technological changes (Santos et al., 2004; Peng, 2006). Basically, the swift development of information technologies and the use of internet in most firms facilitate the interaction with clients, suppliers and consumers (Chen, 1997) which produce important changes in the nature of the organizations. Thus, this new business environment is requiring from SMEs to build and improve their skills based on a specialization of knowledge and innovation in order to improve their productivity and provide products that are more adequate to their consumer than the ones provided by their competition (Lu et al., 2008).

As a result of these changes, most managers are implementing new strategies for the creation, development and retention of knowledge generated by employees which allow the survival and development of such SMEs. Then, the knowledge management is present in the current literature as one of the most important elements that enable the design and implementation of innovation activities as an integral part of the business strategies of the firms (Hitt et al., 1998; Lee \& Grewal, 2004; Miller et al., 2007). Furthermore, the increase in innovation activities can be the result of a more effective 
SMEs knowledge management, particularly the activities of innovation in products, processes and management systems (Moshen \& Khadem, 2010), because the new products, processes and management systems innovations is the result of the interaction between knowledge management and technology (Handzic, 2004).

In this sense, most studies that link knowledge management and innovation have analyzed these elements from the perspective of large firms in developed countries, so there are few ones that have paid attention to SMEs (Thompson \& Leyden, 1983; Acs, 1996), and even fewer ones that are related to the field of developing countries (OECD, 2003; Bozbura, 2007). By comparison, one of the major contributions of this paper is the relationship between knowledge management and SMEs innovation activities in a developing country (Mexico). Also, most researches that are based on these two characteristics have applied qualitative methods; which gives this one another contribution by providing information about how knowledge management contributes to improve the innovation activities in SMEs by means of applying quantitative methods and using structural equation models for such methods.

The rest of the research paper has been structured in the following way: the second section provides a theoretical framework, the previous empirical researches as well as the formulation of hypotheses of the research. The third section deals with the methodology, the sample and the variables used in the research. The analysis of results is made in the fourth section. The final section presents the main conclusions and implications of this paper.

\section{LITERATURE REVIEW}

Knowledge management (KM) has been widely analyzed and discussed in the last decade in different fields and contexts (Lopez et al., 2004) such as the construction industry (Maqsood \& Finegran, 2009), pharmaceutics (Normann \& Ramirez, 1993; Powell, 1998), electronics (Sieloff, 1999), information and communication technology (Rantapuska \& Ihanainen, 2008) as well as manufacturing (Andrews, 1996; Lu et al., 2008; Moshen \& Khadem, 2010).Similarly, it has been identified as an essential element that greatly facilitates the innovation and performance of the Firms (Kamara et al., 2002). 
On one hand, KM has been analyzed and discussed depending on the number of dimensions. One of the most studied classifications is the one that presents two basic types: information and know-how. Information refers to concepts, data or symbols that can be transmitted between two or more companies (Kogut \& Zander, 1992), whereas know-how refers to the accumulation of practical skills or the experience that enable people to perform activities in an easy, efficient way (von Hippel, 1988). With this, the acquisition and processing of information and know-how done by the companies will impact in a different way their results and performance (Lu et al., 2008). Similarly, KM has also been classified as explicit and tacit (Polanyi, 1966). Explicit KM is the one that can be easily transferred from one person to another, whereas tacit $K M$ is the one that is difficult to put into words and access as it commonly develops based on the experience, attitudes, feelings and other factors which can be transferred only by means of interaction with other people (Tsai, 2001; Tsang, 2002; McFadyen \& Cannella, 2004).

On the other hand, the firms that acquire more capabilities so their employees obtain and share the tacit knowledge will be able to create a higher level of innovation in their activities by means of the creation and development of new knowledge, that can be incorporated in the innovation or changes in the products or services that they produce for the benefit of their consumers (Kogut \& Zander, 1992). However, the use and generation of knowledge is different in small and medium-sized enterprises (SMEs), because they have different levels of generated KM into the firm as well as in the outside. As a consequence, these differences can affect the level of innovation and performance significantly (Lu et al., 2008). For this reason, it is important to consider and analyze how the knowledge has been generated, acquired, shared and spread out in the organizations as this will allow SMEs to achieve a higher level of innovation and performance (Huff, 2000; McFadyen \& Cannella, 2004; Argyres \& Silverman, 2004; Hansen et al., 2005; Turner \& Makhija, 2006).

Thus, managers will have to pay more attention to the creation and spread of tacit knowledge inside SMEs, because this type of knowledge is the one that fosters a higher level of innovation in the firms (Lu et al., 2008). At the same time, managers have to improve the processes for the creation of tacit knowledge (Dew et al., 2004; Thorpe et $a l ., 2005)$ since the management style affects the use and creation of both explicit and 
tacit knowledge in a significant way (Ekanem \& Samllbone, 2007). Therefore, managers will have to strengthen the SMEs employees experience, intuition attitude and values just as much as the external resources such as the events with clients, benchmarking and an increasing interaction with the different providers (Bharati \& Chaudhury, 2006), because the different suppliers can strongly promote the development of innovation in SMEs (Rantapuska \& Ihanainen, 2008). That is why the use and development of knowledge in SMEs is usually flexible, unstructured and socially related to the experience and the employees relationships (Thorpe et al., 2005).

The most recent classification of KM in the current literature is the one presented by Bozbura (2007) who considers that KM can be analyzed by means of four dimensions: training and mentoring employees, policies and strategies of knowledge management, knowledge capturing and acquisition from outside, and effects of the organizational culture. It can be understood from this classification that human resources is the most important element in the organization, because it is the resource that generates and develops the required creativity to produce new knowledge that enables companies to improve their level of innovation and development. Accordingly, the implicit knowledge of employees is the essential element that directly affects the activities of the organizations. Thus, the management of human resources is the most important part of SMEs KM (OECD, 2003).

The human resources in the firms, mainly the one of SMEs, increases significantly the tangible activities of the profitable operations such as the acquisition of tools and equipment as well as the intangible activities such as the customer satisfaction (Fitz-enz, 2001). Human resources are so important that every time more and more SMEs are investing important amounts of economic resources in their employees in order to increase their skills, experience and knowledge to improve company's environment in a substantial way (Ulrich, 1997). All this, increases the capabilities of the employees and this can directly affect the SMEs financial performance. Hence, employee's training has a direct relation to knowledge management in the firms (Becker et al., 2001).

Conversely, the mission, vision and management strategies and processes of SMEs can be essential factors that improve skills and strengthen the employees' creativity since 
these elements can be labeled as policies and strategies that directly affect the firms KM. Likewise, the creation and acquisition of knowledge is another essential element for KM because knowledge can be obtained by means of established relationships between SMEs and their clients, suppliers, competition, society and even official institutions. Finally, in order to make employees share the knowledge or information they have with the rest of the firm's members inside their SME, it is necessary to design and use efficient ways of communication, this will allow the firms to have an efficient KM. Then, the working conditions, team work, means of communication to share knowledge and the creation of a favorable environment to promote the free expression of opinions can be defined as the directs effects of organizational culture in KM (Zack, 1999; Bontis, 2000; Buckley \& Carter, 2000; OECD, 2003; Bozbura, 2004; 2007). This model is the one that will be taken for this research in order to measure the KM.

The current literature shows different investigations where they directly relate KM and SMEs innovation activities. One of the most referred papers is the one presented by the researchers Ruggles and Little (1997). In it, a metaphor is presented and explained by the authors in the following way:

"The environment in which new ideas are created can be seen as a greenhouse or garden. Within this greenhouse, gardeners (i.e., managers) try to create conditions that will least inhibit the growth of a prize-winning (high value) flowers. That is, greenhouse gardeners can change the light, moisture, food mixture, etc. in the hope of beneficial results, but they cannot actually make the plants grow. Similarly, management has the ability to influence certain factors; i.e. capital resources, physical surroundings, and employee skill levels, for example, but the actual creation of new ideas is uncontrollable”.

In this model, the soil and food refer mainly to the knowledge generated in the company. It refers to the knowledge and personal experience, to the economic resources such as the acquisition of equipment, tools, and so on, that are accessible for all the personnel. This model also refers to the people, who are considered as the seeds that in which the new concepts can be generated and, at the same time, be the main element of the innovation processes. 
Another model, presented by Swan et al. (1999), postulated two perspectives that were called cognitive model and community model. The cognitive model commonly denotes a perspective in which the generated knowledge can be picked up and codified by each one of the employees of the firms (Sorensen \& Lundh-Snis, 2001), whereas the community or social model is based in the development of technology.

The model presented by Van de Ven and Engleman (2004) considers four basic elements that are derived from the present relation between $\mathrm{KM}$ and innovation. The first one is the human element which consists in motivating the employees of the firm to be more innovative by means of searching and developing both the new knowledge as well the existing knowledge in the SMEs. The second element is the process which consists in the way how the SMEs managers develop and implement new ideas in the organization processes. The third element refers to the structural problems which consist in the use of infrastructure between the company and its suppliers to obtain the knowledge that will help them to generate, facilitate, stand and promote the innovation activities in SMEs. Finally, the fourth element, leadership, consists in the generation and adequate management of an environment that enable facilitate the innovation activities in the organization.

Finally, the model proposed by Tranfield et al. (2006) shows three different stages in the KM-innovation relationship which were called discovery, realization and nourishment. The discovery stage consists in the need to look for and create ideal environments (both internal and external) to develop the innovation potential that lies within the organization. The realization stage consists in how the organization, along with the available elements, can achieve the implementation and development of innovation activities by means of different steps that in the end allow either the development of new products and services or the development of new management processes or methods in the organization.

From the models discussed earlier, it can be inferred that the innovation activities can be the most effective result of $\mathrm{KM}$ in which the innovation of products, processes and management systems are the essential components in the success and development of companies in the new millennium (Mohsen \& Khadem, 2010), due to the fact that the 
new products and services obtained from the interaction between knowledge and technology are changing the way of dealing and competing of businesses in the new economic environment (Handzic, 2004). Hence, it has been demonstrated in the ongoing literature that innovation is a paramount element for the survival and development of SMEs as well as an important objective of the KM activity (Ruggles \& Little, 1997; Nonaka \& Nishiguchi, 2001). Based on this information, the following hypotheses can be formulated:

\section{H1: Higher level of knowledge management, higher level of product innovation}

\section{H2: Higher level of knowledge management, higher level of process innovation}

\section{H3: Higher level of knowledge management, higher level of management systems innovation.}

Figure 1 shows the theoretical model of this research and the general approach of the proposed hypotheses.

\section{FIGURE 1: THEORETICAL MODEL}

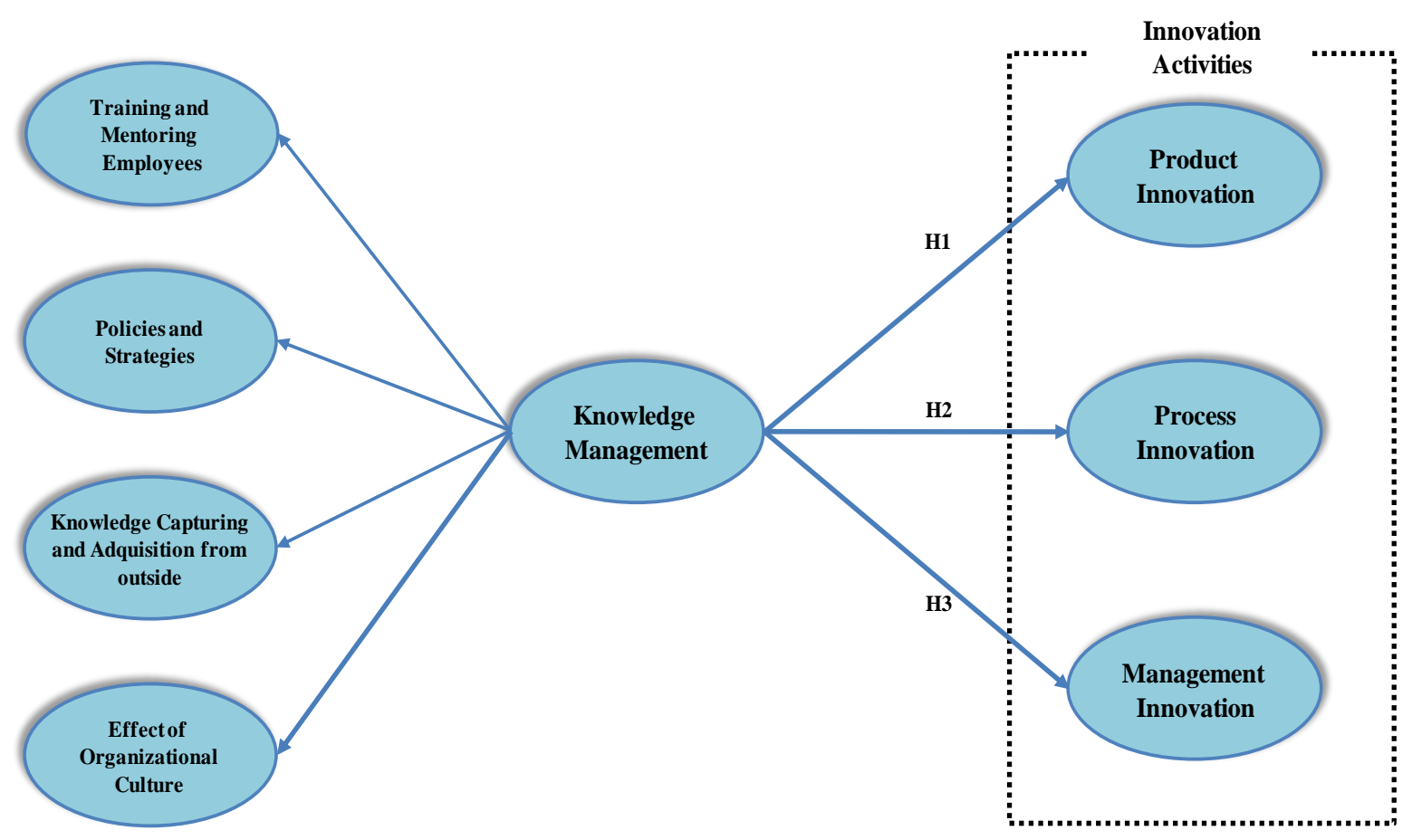




\section{METHODOLOGY}

In order to validate the stated hypotheses within the proposed theoretical model, an empirical research was made by taking into consideration the manufacturing SMEs of Aguascalientes (Mexico). To sum up, the analyzed context is the effect the KM exerts in the innovation activities of manufacturing SMEs from a developing country, which is the case of Mexico. In the first stage of the research, a "Panel Empresarial" took place. In it, different people (such as businesses people, chairpersons, managers, CEOs from financial institutions [both public and private], representatives of Mexican government institutions, as well as university researchers) participated, discussed and analyzed the importance and relationship between KM and SMEs innovation activities in Aguascalientes. The results obtained in this first stage made possible a better understanding of the current situation in this sector and the opportunity to define accurately the survey that was later applied to the SMEs managers.

In order to obtain the reference framework, the methodology used in this paper consisted in obtaining the directory of SMEs which had between 20 and 250 employees. This was made possible with the obtainment of the 2009 directory from the Sistema de Información Empresarial de Mexico (Mexican Business Information System, or SIEM) for Aguascalientes State which accounted for 130 manufacturing firms registered until July 30, 2009. Due to the small amount of companies that fulfilled the required characteristics, it was decided to make a census with a level of reliability of $99 \%$ and a maximum error of $\pm 1 \%$. Similarly, the survey was designed to be answered by the SMEs managers. It was applied in the format of personal interview to the 130 selected firms. From these, only 125 replied back which gives us a response rate of $96 \%$.

\subsection{Development of Steps}

Prior to the analysis of the results of this paper, an analysis of reliability and validity of the used parameters was carried out. Knowledge management was measured by means of four dimensions: training and mentoring employees, policies and strategies of knowledge management, knowledge capturing and acquisition from outside, and effects of the organizational culture. The training of employees was measured with a scale of five items which was adapted from Bontis (2000) and OECD (2003). The scale to 
measure KM policies and strategies was adapted from Bozbura (2004; 2007) with 13 items. The scale to measure the creation and acquisition of external knowledge was adapted from the OECD (2003) and Bozbura (2007) with 5 items. Finally, the scale to measure the effects of organizational culture was adapted from OECD (2003) and Bozbura (2007) with 4 items. All the items were measured in a 5-point Likert scale with $1=$ Strongly disagree and $5=$ Strongly agree.

In order to measure innovation, the survey required from the managers to indicate if the firm had implemented innovation activities during the last two years pior to their application $(1=$ Yes and $0=$ No). In order to measure the importance of the innovative activity, the survey requested the managers to evaluate, by means of a 5-point Likert scale $(1=$ Not important and $5=$ Very important $)$, the product innovation, the process innovation and the management systems innovation (Zahra \& Covin, 1993; Kalantaridis \& Pheby, 1999; Frishammar \& Hörte, 2005; Madrid-Guijarro et al., 2009).

\subsection{Reliability and Validity}

In order to evaluate the reliability and validity of the measurement scales, a Confirmatory Factorial Analysis (CFA) was carried out by using the maximum likelihood method in EQS 6.1 software (Bentler, 2005; Brown, 2006; Byrne, 2006). Similarly, the reliability of the proposed measurement scales is evaluated from Cronbach's alpha coefficient and the composed reliability index (CRI) (Bagozzi \& Yi, 1988). All the values from the scale exceeded the recommended level of 0.7 for Cronbach's alpha as well as the CRI that provides an evidence of the reliability that justifies the internal reliability of the scales (Nunally \& Bernstein, 1994; Hair et al., 1995). Accordingly, other methods of estimation were used when it is assumed that the normality is present. For this, we followed the suggestions from Chou, Bentler and Satorra (1991) and Hu, Bentler and Kano (1992) for the correction of the statistics of the estimation model used. In this way, the robust statistics (Satorra \& Bentler, 1988) will be used to provide a better evidence of the statistical adjustments.

The adjustments used in the method were the Normalized Adjustment Index (NFI), NotNormalized Adjustment Index (NNFI), Comparative Adjustment Index (CFI) and the Root Mean Square of Error Approximation (RMSEA) (Bentler \& Bonnet, 1980; Byrne, 
1989; Bentler, 1990; Hair et al., 1995; Chau, 1997; Heck, 1998). The NFI, NNFI and CFI values between 0.80 and 0.89 represent a reasonable adjustment (Segars \& Grover, 1993), and a value that is equal or higher to 0.90 is an evidence of a good fit (Jöreskog \& Sörbom, 1986; Byrne, 1989; Papke-Shields et al., 2002). The RMSEA values that are inferior to 0.080 are acceptable (Jöreskog \& Sörbom, 1986, Hair et al., 1995).

CFA results are presented in Table 1 and suggest that the theoretical model provides a good fit of data $\left(S-B X^{2}=596.7760 ; \mathrm{df}=356 ; \mathrm{p}=0,000 ; \mathrm{NFI}=0.930 ; \mathrm{NNFI}=0.966\right.$; $\mathrm{CFI}=0.971$; and RMSEA = 0.074). As evidence of the convergent validity, the results from the CFA indicate that all the items of the related factors are significant $(\mathrm{p}<0.001)$, the size of all the standardized factorial loads are superior to 0.60 (Bagozzi \& Yi, 1988) and the average of the standardized factorial loads of every factor exceed without any problems the value of 0.70 (Hair et al., 1995). Finally, the average variance extracted (AVE) was calculated for every pair of constructs, which results in an AVE that is superior to the 0.50 recommended by Fornell and Larcker (1981).

\section{TABLE 1: INTERNAL CONSISTENCY AND CONVERGENT VALIDITY}

\begin{tabular}{|c|c|c|c|c|c|c|c|}
\hline Variable & Indicator & $\begin{array}{l}\text { Factorial } \\
\text { Loadings }\end{array}$ & $\begin{array}{l}\text { Robust } \\
\text { t-Value }\end{array}$ & $\begin{array}{l}\text { Loading } \\
\text { Average }\end{array}$ & $\begin{array}{c}\text { Cronbach's } \\
\text { Alpha }\end{array}$ & $\begin{array}{l}\text { Composite } \\
\text { Reliability }\end{array}$ & $\begin{array}{l}\text { Average } \\
\text { Viability }\end{array}$ \\
\hline \multirow{4}{*}{$\begin{array}{l}\text { Training and mentoring } \\
\text { emp loy ees of KM }\end{array}$} & BFT 1 & $0.757 * * *$ & $1.000^{\mathrm{a}}$ & \multirow{4}{*}{0.809} & \multirow{4}{*}{0.882} & \multirow{4}{*}{0.884} & \multirow{4}{*}{0.656} \\
\hline & BFT3 & $0.811 * * *$ & 9.342 & & & & \\
\hline & BFT4 & $0.842 * * *$ & 10.074 & & & & \\
\hline & BFT5 & $0.826 * * *$ & 10.886 & & & & \\
\hline \multirow{9}{*}{$\begin{array}{c}\text { Policies and strategies } \\
\text { of KM }\end{array}$} & BPE1 & $0.807 * * *$ & $1.000^{\mathrm{a}}$ & \multirow{9}{*}{0.727} & \multirow{9}{*}{0.907} & \multirow{9}{*}{0.910} & \multirow{9}{*}{0.532} \\
\hline & BPE2 & $0.798 * * *$ & 12.260 & & & & \\
\hline & BPE3 & $0.776 * * *$ & 13.257 & & & & \\
\hline & BPE4 & $0.730 * * *$ & 13.118 & & & & \\
\hline & BPE6 & $0.729 * * *$ & 10.672 & & & & \\
\hline & BPE7 & $0.647 * * *$ & 8.240 & & & & \\
\hline & BPE9 & $0.678 * * *$ & 11.370 & & & & \\
\hline & BPE12 & $0.618 * * *$ & 11.523 & & & & \\
\hline & BPE13 & $0.757 * * *$ & 18.705 & & & & \\
\hline \multirow{5}{*}{$\begin{array}{c}\text { Know ledge capturing } \\
\text { and acquisition from } \\
\text { outside }\end{array}$} & BKO1 & $0.750^{* * * *}$ & $1.000^{\mathrm{a}}$ & \multirow{5}{*}{0.730} & \multirow{5}{*}{0.849} & \multirow{5}{*}{0.851} & \multirow{5}{*}{0.535} \\
\hline & BKO2 & $0.776 * * *$ & 12.382 & & & & \\
\hline & ВКО3 & $0.764 * * *$ & 10.143 & & & & \\
\hline & BKO4 & $0.651 * * *$ & 9.855 & & & & \\
\hline & BKO5 & $0.709 * * *$ & 11.534 & & & & \\
\hline \multirow{4}{*}{$\begin{array}{c}\text { Effects of organizational } \\
\text { culture }\end{array}$} & BOC1 & $0.821 * * *$ & $1.000^{\mathrm{a}}$ & \multirow{4}{*}{0.835} & \multirow{4}{*}{0.896} & \multirow{4}{*}{0.903} & \multirow{4}{*}{0.701} \\
\hline & BOC2 & $0.819 * * *$ & 13.459 & & & & \\
\hline & BOC3 & $0.923 * * *$ & 19.383 & & & & \\
\hline & BOC4 & $0.778 * * *$ & 11.299 & & & & \\
\hline \multirow{2}{*}{ Product innovation } & INP1 & $0.888 * * *$ & $1.000^{\mathrm{a}}$ & \multirow{2}{*}{0.907} & \multirow{2}{*}{0.904} & \multirow{2}{*}{0.903} & \multirow{2}{*}{0.824} \\
\hline & INP2 & $0.927 * * *$ & 15.081 & & & & \\
\hline \multirow{2}{*}{ Process innovation } & INR 1 & $0.962 * * *$ & $1.000^{\mathrm{a}}$ & \multirow{2}{*}{0.954} & \multirow{2}{*}{0.952} & \multirow{2}{*}{0.953} & \multirow{2}{*}{0.911} \\
\hline & INR2 & $0.947 * * *$ & 32.240 & & & & \\
\hline & ING 1 & $0.946 * * *$ & $1.000^{\mathrm{a}}$ & & & & \\
\hline Management sy stems & ING2 & $0.980 * * *$ & 35.109 & 0.957 & 0.969 & 0.971 & 0.917 \\
\hline & ING3 & $0.946 * * *$ & 27.378 & & & & \\
\hline$S-B X^{2}(\mathrm{df}=356)=5$ & 5.7760 & 0.000 & $=0.930$ & $\mathrm{NNFI}=\mathrm{O}$ & $; \quad C F I=C$ & 71; RMSI & $=0.074$ \\
\hline
\end{tabular}


In regard to the evidence of discriminant validity, the measurement is given in two ways that can be observed in Table 2. First, with a confidentiality interval of 95\%, none of the individual elements of the latent factors from correlation matrix contain the value 1.0 (Anderson \& Gerbing, 1988). Second, the variance extracted between each pair of constructs is superior to its corresponding AVE (Fornell \& Larcker, 1981). Based on these criteria, it can be concluded that the different measurements used in this paper show sufficient evidence of reliability as well as convergent and discriminant validity.

TABLE 2: DISCRIMINANT VALIDITY

\begin{tabular}{|c|c|c|c|c|c|c|c|}
\hline Variables & 1 & 2 & 3 & 4 & 5 & 6 & 7 \\
\hline \begin{tabular}{c|c|}
1. \\
$\begin{array}{c}\text { Training and mentoring } \\
\text { employees of KM }\end{array}$ \\
\end{tabular} & 0.656 & 0.171 & 0.139 & 0.194 & 0.128 & 0.094 & 0.104 \\
\hline \begin{tabular}{|c|}
2. \\
Policies and strategies of \\
KM
\end{tabular} & $0.268-0.560$ & 0.532 & 0.166 & 0.164 & 0.109 & 0.145 & 0.107 \\
\hline $\begin{array}{c}3 . \\
\begin{array}{c}\text { Knowledge capturing } \\
\text { and acquisition from } \\
\text { outside }\end{array} \\
\end{array}$ & $0.236-0.512$ & $0.278-0.538$ & 0.535 & 0.126 & 0.115 & 0.141 & 0.149 \\
\hline \begin{tabular}{|c|}
4. \\
$\begin{array}{c}\text { Effects of organizational } \\
\text { culture }\end{array}$ \\
\end{tabular} & $0.305-0.577$ & $0.267-0.543$ & $0.229-0.481$ & 0.701 & 0.108 & 0.126 & 0.098 \\
\hline $\begin{array}{c}5 . \\
\text { Product innovation }\end{array}$ & $0.211-0.507$ & $0.169-0.493$ & $0.200-0.480$ & $0.148-0.512$ & 0.824 & 0.648 & 0.454 \\
\hline $\begin{array}{c}6 . \\
\text { Process innovation }\end{array}$ & $0.158-0.458$ & $0.212-0.552$ & $0.240-0.512$ & $0.171-0.539$ & $0.649-0.961$ & 0.911 & 0.583 \\
\hline $\begin{array}{c}7 . \\
\begin{array}{c}\text { Management systems } \\
\text { innovation }\end{array} \\
\end{array}$ & $0.174-0.474$ & $0.172-0.484$ & $0.205-0.569$ & $0.146-0.482$ & $0.514-0.834$ & $0.654-0.874$ & 0.917 \\
\hline
\end{tabular}

Diagonal represent the average variance extracted, while above the diagonal the shared variance (squared correlations) are represented. Below the diagonal the 95\% confidence interval for the estimated factors correlations is provided.

\section{RESULTS}

The theoretical model was analyzed with this research by using the structural equations model (SEM) with the EQS 6.1 software (Bentler, 2005; Byrne, 2006; Brown, 2006). In order to obtain the statistical results of the research hypotheses, a SEM was carried out with the same variables to prove the structure of the model and obtain the results that could allow the contrast of the established hypotheses. The nomological validity of the theoretical model was analyzed by the chi-square performance test in which the theoretical model was compared with the measurement model. The results indicate that the non-significant differences of the theoretical model are good in the explanation of the relations observed between the latent constructs (Anderson \& Gerbing, 1988; Hatcher, 1994). The final results obtained from SEM are presented in Table 3. 
TABLE 3: STRUCTURAL EQUATION MODEL RESULTS

\begin{tabular}{|c|c|c|c|}
\hline Hypothesis & Path & $\begin{array}{l}\text { Standardized } \\
\text { path coeffcients }\end{array}$ & $\begin{array}{l}\text { Robust } \\
\text { t-value }\end{array}$ \\
\hline $\begin{array}{l}\text { H1: Higher knowledge management, higher } \\
\text { product innovation. }\end{array}$ & Knowledge Management $\longrightarrow$ Product Innovation & $0.320 * * *$ & 8.313 \\
\hline $\begin{array}{l}\text { H2: Higher knowledge management, higher } \\
\text { process innovation. }\end{array}$ & Knowledge Management $\longrightarrow$ Process Innovation & $0.380 * * *$ & 9.188 \\
\hline $\begin{array}{l}\text { H3: Higher knowledge management, higher } \\
\text { management systems innovation. }\end{array}$ & Knowledge Management $\longrightarrow$ Management Innovation & $0.456 * * *$ & 10.573 \\
\hline \multicolumn{4}{|c|}{$S-B X_{(357)}^{2}=267.5603 ; \mathrm{p}<0.000 ; \quad \mathrm{NFI}=0.894 ; \mathrm{NNFI}=0.948 ; \mathrm{CFI}=0.965 ; \quad \mathrm{RMSEA}=0.074$} \\
\hline
\end{tabular}

In regard to hypothesis H1, the results obtained (seen in Table 3), $\beta=0.320, p<0.001$, indicate that knowledge management has significant and positive effects in product innovation. In regard to hypothesis $\mathbf{H 2}$, the results obtained, $\beta=0.380, p<0.001$, indicate that knowledge management has significant and positive effects in process innovation. Finally, in regard to hypothesis H3, the results obtained, $\beta=0.456, p<$ 0.001, indicate that knowledge management has significant and positive effects in management systems innovation. To sum up, it can be proved that knowledge management has significant and positive effects in SMEs innovation activities.

\section{DISCUSSION AND CONCLUSIONS}

The results obtained in this research show that KM encourages the innovation activities in three different ways. First, it helps SMEs to locate innovative knowledge in the external environment of the organization, own that knowledge and transfer it to all the personnel of the company and incorporate it efficiently to the productive activities, which generates changes or improvements to the products created. Thus, the knowledge generated in universities, research centers, government institutions and other organizations that produce similar or identical products allows SMEs to acquire and develop knowledge that turns into superior skills of the human resources, which derives in an improvement of the competitive advantage of firms by means of the generation of new products in the target market. Similarly, in a market that is every time more globalized and highly competitive, just like the one where most SMEs are currently established, the survival and development of this kind of firms depends on the constant 
change or improvement of the products made to adapt them to the constant preferences and needs of the consumers; and in order to do this, they need the knowledge generated outside the firms.

Second, KM helps SMEs to improve their level of competitiveness by enhancing the production processes because it gets, assimilates and uses the innovative knowledge from the external environment in favor of the organization. KM usually promotes and regulates the adoption cycle of the innovation activities of the firms, mainly the production processes, because it requires important monetary investments, on one hand, for the automation of productive processes by acquiring new technology; and, on the other hand, to have an efficient record of the production and predictive, corrective maintenance of machinery and equipment. Similarly, it is necessary to have innovative initiatives in the delivery methods, higher levels of cooperation with the suppliers to diminish risks and a more efficient and effective production schedule. Hence, SMEs requires external innovative knowledge that is spread in the industry so KM enables this process into the organization in order to generate new knowledge. This will facilitate its fast internal dissemination of the operational processes of the firms which will cause changes or improvements in the production processes.

Third, KM helps SMEs to get a better development by means of a change or improvement in the management systems. The limited use of explicit or processual knowledge that exists inside SMEs as well as the tacit knowledge that is in the people's skills and experience affects the specific behavior of employees and the organizational culture, which usually causes that different SMEs do not accept the new knowledge that is outside the firm. That is why managers will have to put into effect changes or improvements in the management systems of SMEs to facilitate the transference of explicit and tacit knowledge among all the employees in the organization. Thus, the changes or improvements in the management systems will have to guarantee the optimal use of the available knowledge (both inside and outside the organization), because the use of internal knowledge can create a high demand of the external available knowledge that would directly result in improving the management systems in order to use such knowledge efficiently. This could be perceived in a better output and a better level of innovation in the firms. In order to take external knowledge and incorporate it with the 
existing knowledge in the SMEs it is necessary to improve and upgrade the process of $\mathrm{KM}$ and provide the necessary skills so the firms to become learning organizations.

The main objective of this research aimed to indentify the relationship between KM and innovation by using a sample of 125 Mexican SMEs manufacturing firms. The empirical evidence in this paper allows us to conclude that $\mathrm{KM}$ has a positive and direct effect in product innovation as well as the processes and management systems of manufacturing SMEs. These results are similar to the ones obtained by Thompson and Leyden (1983), Acs (1996) and Lu et al. (2008), where they concluded that instead of having SMEs generating new knowledge they normally look for and get new knowledge outside the organization through social bonds that they keep with clients and suppliers. For this reason, it can be concluded that a good combination of internal and external knowledge can make SMEs more innovative.

This research has some limitations. Firstly, the sample only considered manufacturing SMEs with 20 to 250 employees in Aguascalientes (Mexico), so further investigations might take into account smaller firms, from other sectors and from other country. Secondly, the research only considered four dimensions or factors in order to measure $\mathrm{KM}$; further investigations might consider other variables such as human resources, aptitude, creativity, level of education and working experience, among others. Similarly, the research could include moderating variables such as the characteristics of the industry, the ownership of the firms, the competitive strategy and the structure of the organization. Finally, another limitation of this research is the fact that the survey was done only with the SMEs managers. It would be interesting for future investigations to consider in the survey the employees, clients and suppliers of the organization so it is possible to know the opinion of other participants of the firms.

\section{REFERENCES}

Acs, Z.J. (1996), Small firms and economic growth, In Small Business in the Modern Economy, Acs, Z.J., Carlsson, B. \& Thurik, A.R. (Eds.) T.J. Press: Padstrow, Cornwall, 1-62.

Anderson, J. and Gerbing, D. (1988), "Structural equation modeling in practice: a review and recommended two-step approach", Psychological Bulletin, 13, 411423. 
Argyres, N. and Silverman, B. (2004), "R\&D, organization structure, and the development of corporate technological knowledge", Strategic Management Journal, 25, 929-958.

Audretsch, D. and Thurik, R. (2000), "Capitalism and democracy in the $21^{\text {st }}$ century: from the managed to the entrepreneurial economy", Journal of Evolutionary Economics, 10, 17-34.

Audretsch, D. and Thurik, R. (2001), "What's new about the new economy: sources of growth in the managed and entrepreneurial economies", Industrial and Corporate Change, 19, 759-821.

Audretsch, D. and Thurik, R. (2004), "A model of entrepreneurial economy", International Journal of Entrepreneurship Education, 2(2), 143-166.

Bagozzi, R.P. and Yi, Y. (1988), "On the evaluation of structural equation models", Journal of the Academy of Marketing Science, 16(1), 74-94.

Becker, B.E., Huselid, M.A. and Ulrich, D. (2001), The HR scorecard. Boston, MA: Harvard Business School Press.

Bentler, P.M. and Bonnet, D. (1980), "Significance tests and goodness of fit in analysis of covariance structures", Psychological Bulletin, 88, 588-606.

Bentler, P.M. (1990), "Comparative fit indexes in structural models", Psychological Bulletin, 107(2), 238-246.

Bentler, P.M. (2005), EQS 6 Structural Equations Program Manual. Encino, CA: Multivariate Software (www.mvsoft.com).

Bharati, P. and Chaudhury, A. (2006), "Studying the current status of technology adoption", Communications of the ACM, 49(10), 88-93.

Bontis, N. (2000), "Intellectual capital and business performance in Malaysian industries", Journal of Intellectual Capital, 1(1), 85-100.

Bozbura, F.T. (2004), "Measurement and application of intellectual capital in Turkey", The Learning Organization: An International Journal, 11(4/5), 357-367.

Bozbura, F.T. (2007), "Knowledge management practices in Turkish SMEs", Journal of Enterprise Information Management, 20(2), 209-221.

Brown, T. (2006), Confirmatory Factor Analysis for Applied Research. NY: The Guilford Press.

Buckley, P.J. and Carter, M.J. (2000), "Knowledge management in global technology markets", Long Range Planning, 33, 55-71.

Byrne, B. (2006), Structural Equation Modeling with EQS, Basic Concepts, Applications, and Programming. London: 2th edition, LEA Publishers.

Byrne, B.M. (1989), A Primer of LISREL: Basic Applications and Programming for Confirmatory Factor Analysis Analytic Models, NY: Springer.

Chau, P. (1997), "Reexamining a model for evaluating information center success using a structural equation modeling approach", Decision Sciences, 28(2), 309-334.

Chen, S. (1997), "A new paradigm for knowledge-based competition: building and industry through knowledge sharing", Technology Analysis \& Strategic Management, 9, 437-452.

Chirico, F. (2008), "Knowledge accumulation in family firms: evidence from four case studies", International Small Business Journal, 26(4), 433-462.

Chou, C.P., Bentler, P.M. and Satorra, A. (1991), "Scaled test statistics and robust standard errors for nonnormal data in covariance structure analysis", British Journal of Mathematical and Statistical Psychology, 44, 347-357. 
Corso, M., Martini, A., Pellegrini, L. and Paolucci, E. (2003), "Technological and organizational tools for knowledge management: in search of configurations", Small Business Economics, 21(4), 397-408.

Dew, N., Velamuri, S.R. and Venkataraman, S. (2004), "Dispersed knowledge and an entrepreneurial theory of the firm", Journal of Business Venturing, 19(5), 659679.

Drucker, P. (1994), “The age of social transformation", The Atlantic Monthly, 274, 5380.

Eisenhardt, K. and Martin, J. (2000), “Dynamic capabilities: what are they?”, Strategic Management Journal, 21, 1105-1121.

Ekanem, I. and Smallbone, D. (2007), "Learning in small manufacturing firms: The case of investment decision-making behavior", International Small Business Journal, 25(2), 107-129.

Fitz-enz, J. (2001), The ROI of Human Capital. New York, NY: American Management Association.

Fornell, C. and Larcker, D. (1981), "Evaluating structural equation models with unobservable variables and measurement error", Journal of Marketing Research, $18,39-50$.

Frishammar, J. and Hörte, S. (2005), "Managing external information in manufacturing firms: the impact of innovation performance", Journal of Product Innovation Management, 22, 251-266.

Hair, J.F., Anderson, R.E., Tatham, R.L. and Black, W.C. (1995), Multivariate Data Analysis with Readings. NY: Prentice-Hall.

Handzic, M. (2004), Knowledge Management through the Technology Glass, Singapore: World Scientific Publishing Co. Pte. Ltd.

Hansen, M., Mors, M. and Lovas, B. (2005), "Knowledge sharing in organizations: multiple networks, multiple phases", Academy Of management Journal, 48, 776793.

Hatcher, L. (1994), A Step by Step Approach to Using the SAS System for Factor Analysis and Structural Equation Modeling, Cary, NC: SAS Institute Inc.

Heck, R.H. (1998), "Factor analysis: exploratory and confirmatory approaches", In Marcoulides, G.A. (Ed.), Modern Methods for Business Research, Mahwah, NJ: Lawrence Erlbaum Associates, 177-215.

Hitt, M., Keats, B. and DeMarie, S. (1998), "Navigating in the new competitive landscape: building competitive advantage and strategy flexibility in the 21th century", Academy of Management Executive, 12, 22-42.

Hu, L.T., Bentler, P.M. and Kano, Y. (1992), "Can test statistics in covariance structure analysis be trusted?", Psychological Bulletin, 112, 351-362.

Huff, A. (2000), "Changes in organizational knowledge production", Academy of Management Review, 25, 288-293.

Jöreskog, K.G. and Sörbom, D. (1986), LISREL VI: Analysis of Linear Structural Relationships by Maximum Likelihood, Instrumental Variables and Square Methods, Moorsville, IN: Scientific Software.

Kalantaridis, C. and Pheby, J. (1999), "Processes of innovation among manufacturing SMEs: the experience of Bedfordshire", Entrepreneurship and Regional Development, 11, 57-78.

Kamara, J.M., Anumba, C.J. and Carrillo, P.M. (2002), "A CLEVER approach to selecting a knowledge management strategy", International Journal of Project Management, 20, 205-211. 
Kogut, B. and Zander, U. (1992), "Knowledge of the firm, combinative capabilities, and the replication of technology", Organization Science, 3, 383-397.

Lee, R.P. and Grewal, R. (2004),"Strategic responses to new technologies and their impact on firm performance", Journal of Marketing, 68, 157-171.

Lopez, S.P., Montes-Peon, J.M. and Vazquez-Ordas, C.J. (2004), "Managing knowledge: the link between culture and organizational learning", Journal of Knowledge Management, 8(6), 93-104.

Lu, Y., Tsang, W.K. and Peng, M.W. (2008), "Knowledge management and innovation strategy in the Asia Pacific: toward an institution-based view", Asia Pacific Journal of Management, 25, 361-374.

Madrid-Guijarro, A., Garcia-Perez-De-Lema, D. and Van Auken, H. (2009), "Barriers to innovation among Spanish manufacturing SMEs", Journal of Small Business Management, 47(4), 465-488.

Maqsood, T. and Finegan, A.D. (2009), "A knowledge management approach to innovation and learning in the construction industry", International Journal of Managing Projects Business, 2(2), 297-307.

McFadyen, M. and Cannella, A. Jr. (2004), "Social capital and knowledge creation: Diminishing returns of the number and strength of change relationships", Academy of Management Journal, 47, 735-746.

Mhosen, S.A. and Khadem, S.A. (2010), "The relationship between knowledge management practices and innovation level in organizations: case study of subcompanies of selected corporations in the city of Esfahan", Journal of Business Case Studies, 6(1), 89-97.

Miller, D., Fern, M. and Cardinal, L. (2007), “The use of knowledge for technological innovation within diversified firms", Academy of Management Journal, 50, 308328.

Normann, R. and Ramirez, R. (1993), "From value chain to value constellation: designing interactive strategy", Harvard Business Review, 71(4), 65-77.

Nunnally, J.C. and Bernstein, I.H. (1994), Psychometric Theory. New York: 3a Ed. McGraw-Hill.

OECD (Organization for Economic Co-operation and Development) (2003), Measuring Knowledge Management in the Business Sector, OECD/Minister of Industry, Ottawa.

Papke-Shields, K.E., Malhotra, M.J. and Grover, V. (2002), "Strategic manufacturing planning systems and their linkage to planning system success", Decision Science, 13(1), 1-30.

Peng, M.W. (2006), Global Strategy. Cincinnati: South-Western Thomson.

Polanyi, M. (1996), The Tacit Dimension. New York: Anchor Day Books

Powell, W.W. (1998), "Learning from collaboration: knowledge networks in the biotechnology and pharmaceutical industries", California Management Review, 40(3), 224-240.

Rantapuska, T. and Ihanainen, O. (2008), "Knowledge use in ICT investment decision making of SMEs", Journal of Enterprise Information Management, 21(6), 585596.

Ruggles, R. and Little, R. (1997), "Knowledge management and innovation: an initial exploration", Center for Business Innovationism.

Santos, J., Doz, Y. and Williamson, P. (2004), "Is your innovation process global?", Sloan Management Review, 45(4), 31-37. 
Satorra, A. and Bentler, P.M. (1988), "Scaling corrections for chi square statistics in covariance structure analysis", American Statistics Association 1988 Proceedings of the Business and Economic Sections, 208-313.

Segars, A.H. and Grover, V. (1993),"Re-examining perceived ease of use and usefulness: a confirmatory factor analysis", MIS Quarterly, 17(4), pp. 517-525.

Sieloff, C.G. (1999), "If only HP knew what HP knows': the roots of knowledge management at Hewlett-Packard", Journal of Knowledge Management, 3(1), 4753.

Sorensen, C. and Lundh-Snis, U. (2001), "Innovation through knowledge codification", Journal of Information Technology, 16, 83-97.

Swan, J., Newell, S., Scarbrough, H. and Hislop, D. (1999), "Knowledge management and innovation: networks and networking", Journal of Knowledge Management, 3(3), 262-275.

Teece, D.J., Pisano, G. and Shuen, A. (1997), "Dynamic capabilities and strategic management", Strategic Management Journal, 18(7), 509-533.

Thompson, J.H. and Leyden, D.R. (1983), "The United States of America", In The Small Firm - An International Survey, Storey, D.J. (Ed.). London: Croom Helm, 7-45.

Thorpe, R. Holt, R. Macpherson, A. and Pittaway, L. (2005), "Using knowledge within small and medium-sized firms: a systematic review of the evidence", International Journal of Management Review, 7(4), 257-281.

Tranfield, D., Young, M., Partington, D., Bessant, J. and Sapsed, J. (2006), “Building knowledge management capabilities for innovation projects", Imperial College Press, 3, 126-149.

Tsai, W. (2001), "Knowledge transfer in interorganizational networks: effect of network position and absorptive capacity on business unit innovation and performance", Academy of management Journal, 44, 996-1004.

Tsang, E.W.K. (2002), "Acquiring knowledge by foreign partners from international joint ventures in a transition economy: learning-by-doing and learning myopia", Strategic Management Journal, 23, 835-854.

Turner, K. and Makhija, M. (2006), "The role of organizational control in managing knowledge", Academy of Management Review, 31, 197-217.

Ulrich, D. (1997), Human Resource Champions. Boston, MA: Harvard Business School Press.

Van de Ven, A. and Engleman, R. (2004), "Central problems in managing corporate innovation and entrepreneurship", Advances in Entrepreneurship, Firm Emergence and Growth, 7, 47-72.

Van de Ven, A. (2004), "The context-specific nature of competence and corporate development", Asia Pacific Journal of Management, 21, 123-147.

von Hippel, E. (1998), The Source of Innovation. MA: MIT, Cambridge.

Zach, M.H. (1999), "Managing codified knowledge", Sloan Management Review, summer, 45-58.

Zahra, S. and Covin, J. (1993), "Business strategy, technology policy and firm performance", Strategic Management Journal, 14(6), 451-478. 